Quim. Nova, Vol. 35, No. 2, 438-443, 2012

\title{
THE CONTRIBUTIONS OF HENRI VICTOR REGNAULT IN THE CONTEXT OF ORGANIC CHEMISTRY OF THE FIRST HALF OF THE NINETEENTH CENTURY
}

\author{
Simón Reif-Acherman \\ Escuela de Ingeniería Química, Universidad del Valle, A.A. 25360 Unicentro, Cali, Colombia
}

Recebido em 13/2/11; aceito em 1/8/11; publicado na web em 20/9/11

\begin{abstract}
A very little known aspect of the scientific career of Regnault is his contribution to the emerging organic chemistry in the first half of the nineteenth century. The purpose of this article is not only to describe two of his most important researches in this field, as were the discovery of two series of halogenated derivates of certain organic compounds and the precise identification of some of the then recently discovered alkaloids, but also the main features that identified his research method. With the involvement in these subjects, Regnault unintentionally positioned himself in the midst of some of the polemics about the classification of organic compounds that characterized this age of science.
\end{abstract}

Keywords: Henri Victor Regnault; history; history of chemistry.

\section{INTRODUCTION}

The name of the French scientist Henri Victor Regnault (18101878 ) is widely recognized by historians of science because of his numerous researches on physical properties of substances and their mixtures. The meticulous compilation of an amazing amount of data that he measured over about three decades of properties, such as densities and compressibilities of gases and liquids, heat capacities and dilatation coefficients of gases, vapor pressures and speeds of sound, among others, do credit him to be considered as the very probably greatest experimentalist of the nineteenth century. His works on chemistry have not received, however, similar diffusion. Several classical and modern books do not include the name of Regnault in the index of the people that contributed to the history of this science, ${ }^{1}$ and others mention only very briefly and without relevant details his researches in this field. ${ }^{2}$ The purpose of this article is to show the researches Regnault carried out in organic chemistry in the first period of his successful scientific career, and how they contributed to the definitive establishment of some polemic theories and techniques of his time.

\section{BRIEF PROFILE AND BEGINNINGS IN CHEMISTRY ${ }^{3}$}

Henri Victor Regnault (Figure 1) was born on July 21, 1810, in Aix-la-Chapelle, France (now Aachen, Germany), the older of two children of André Privat Regnault, a military civil engineer and Captain in Napoleon's Imperial Corps, and Marie Thèrése Massardo, the daughter of a Belgian hotelier of Italian descent. After the death of their parents, Regnault and his sister were taken under the care of Jean-Baptiste Clement, a close army friend of their father, and his wife, who supervised the youth's education and found employment for him in a Parisian draper's shop. After overcoming several personal and health difficulties he was admitted into the École Polytechnique in 1830, where he graduated as the top student of his class. ${ }^{4}$ Regnault's professors included Joseph Louis Gay-Lussac (1778-1850) and Louis Jacques Thénard (1777-1857) in chemistry, and Pierre Louis Dulong (1785-1838) Claude Servais Mathias Pouillet (1791-1868) in physics. In 1832 Regnault joined the École des Mines, where he received especially outstanding grades in chemistry and design. As he was not formally allowed to graduate for not having completed a

*e-mail: sireache@univalle.edu.co regular three-year course of study in only two years, Regnault decided to complement his formation by visiting different countries. In 1834 he traveled first to Belgium and then to the Harz mountains in central Germany to study silver-mining techniques, and in 1835 to Würtemberg in southwestern Germany and to Switzerland to analyze the salinity of thermal waters and the metallurgical processes in iron foundries in the nearby Principality of Furstemberg. ${ }^{5}$ He summarized the results of his travels in four memoirs that he deposited in the library of the École des Mines.

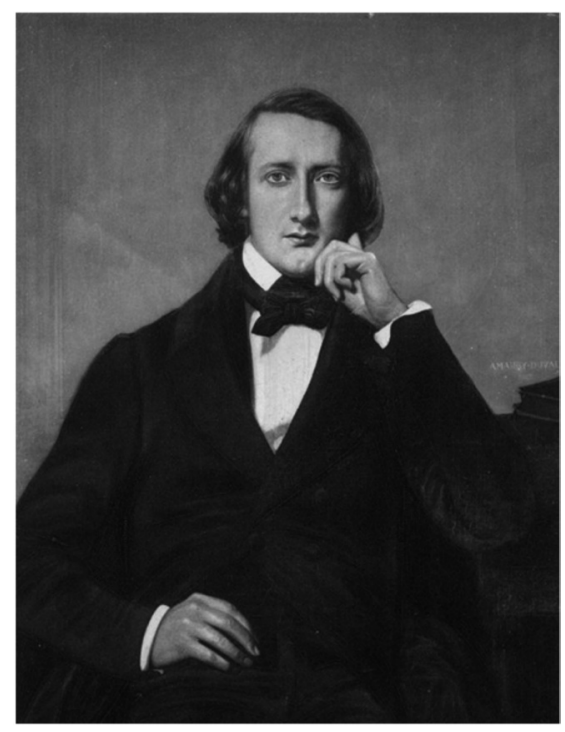

Figure 1. Henri Victor Regnault (1810-1878) as painted by his son Henri (1843-1871). Credit: Collections of the École Polytechnique and the École des Mines

In 1835 administrators at the École des Mines designated Regnault to fill a vacant position at Rive-de-Gier, a commune in the Loire department in central France, but they reversed their decision only two weeks later and appointed him as a laboratory assistant to the chemist Pierre Berthier (1782-1861) at the École des Mines. ${ }^{6}$ Berthier, graduated as Regnault first from the École Polytechnique and later from the École des Mines, had acquired great reputation mainly in geology, mineralogy and metallurgy thanks to the development of 
important analytical techniques of minerals and metalliferous ores, clays and mineral waters among others, which won him the election as chief of the Laboratory of the École des Mines in 1816 and Member of the Mineralogy Section of the Académie des Sciences nine years later. $^{7}$ The by then particular teaching style at the École, by which Berthier turned the best students into his closest collaborators, allowed him to teach chemistry and the optimal use of the corresponding necessary resources by working with them. It is very probably not a speculative matter to affirm that these particularities, together with the simplicity, acceptable accuracy and practicality that characterized most of the analytical techniques devised by Berthier, must have decisively contributed to strengthen the Regnault's interests on this subject and its later application to industrial issues. It was during the years Regnault shared activities with Berthier that he adopted two aspects that characterized all his work: the absolute respect for experimentation and the deep contempt for vain theories.

Regnault was then granted with a three-month leave for going to the University of Lyon to replace the Dean and Professor of Chemistry Jean-Baptiste Boussingault (1802-1887), who was moving to the University of Paris (the Sorbonne) to take over various duties of Louis-Jacques Thenard, Once this opportunity concluded, Regnault returned to Paris on June 19, 1836 to formally receive the title of engineer at the École des Mines and married Clémence Clement, the only daughter of his guardians in his youth. Just this year it was suggested by Regnault's former professors at the École Polytechnique that he should offer himself as a candidate for the position of répétiteur for Gay-Lussac, which had become vacant, ${ }^{8}$ and which would involve repeating the work that Gay-Lussac had covered for his students in his chemistry lectures, as well as other duties, such as conducting oral examinations and ordering and storing chemicals and apparatus. Gay-Lussac was initially inclined to appoint Auguste Laurent (1807-1853), who unlike Regnault did not have a position in Paris, but the Council of Public Instruction unanimously favored Regnault, and Gay-Lussac accepted its judgment.

Thus, in line with the common French practice at the time of accumulating positions, Regnault now held two, one at the École des Mines and one at the École Polytechnique, where over the course of the next two years he began to take over some of Gay-Lussac's lectures. When Gay-Lussac resigned as Professor of Chemistry on November $18,1840,{ }^{8}$ the Academy of Sciences unanimously recommended that Regnault be appointed as his successor, ${ }^{9}$ a recommendation that was confirmed on December 11, 1840. Regnault stayed at this position for more than three decades.

\section{HALOGENATED COMPOUNDS}

A visit to the laboratories of the University of Giessen marked the entering upon of Regnault in the field of research. The subject was organic chemistry, a branch of chemical science which had just sprung into existence under the hands of chemists as Justus von Liebig (1803-1873) and Friedrich Wöhler (1800-1882) in Germany, and Auguste Laurent (1807-1853) and Jean Baptiste André Dumas (1800-1884) in France, among others. The investigation in the new carbon-chemistry about the constitution of organic compounds and their substitution reactions, especially from a pure science viewpoint and still not with a look on their potential applications, had become a primordial objective and its development would become in the key element that would essentially change the views respecting these classes of compounds. Giessen, under the direction of Liebig, was the place where the systematic instruction in experimental chemistry had been introduced by first time in the 1830's and represented one of the most appropriate centers for the promotion of this class of scientific investigation. Its international renown attracted the attention of many students from foreign countries, being France one of the most remarked especially because of Liebig's association with the French chemist and physicist Joseph Louis Gay-Lussac (1778-1850) during his stay at Paris between 1822 and $1824 .{ }^{10}$ Jules Gay-Lussac (1810-1877), the son of Joseph Louis, was precisely one of the first Liebig's French students in $1831,{ }^{8}$ being followed by Regnault and a list of other ten French chemists between 1830 and 1835, which includes so remarked names as those of Théophile-Jules Pelouze (1807-1867), Adolphe Wurtz (1817-1884) and Charles-Frédéric Gerhardt (1816-1856). ${ }^{11}$ Regnault arrived to Giessen in 1835, and although, along with Pelouze, were not formally part of the Liebig's teaching program, he spent significant time there to become familiar at first hand with the methods in use in the laboratory and to benefit from the continuous contact with who was considered by then one of the leading research chemists in the world. ${ }^{12}$

The central subject of interest in Giessen for German and foreign students, including Regnault, was then the improvement Liebig had done for the determination of the carbon-hydrogen content of organic compounds. This development was a response to the difficulties he had identified in older methods, mainly related with the analysis of the very recently discovered plant alkaloids. The standard technique in use, developed between 1811 and 1815 as the result of a unplanned collaboration between Gay-Lussac, the also French chemist Louis Jacques Thénard (1777-1857), and the Swedish Jöns Jacob Berzelius (1779-1848), ${ }^{13}$ and later slightly improved by Liebig and Gay-Lussac, ${ }^{14}$ showed severe limitations of different types. Although the technique showed great degree of inaccuracy specially working with large-weight compounds, its main difficulty was related with the determination of nitrogen. The impossibility of excluding the trace amounts of atmospheric nitrogen and the difficulty for collecting pure nitrogen from the combustion procedure included in the technique usually led to different reports of elementary proportions for the same compounds. The new five-bulbed apparatus Liebig designed in October 1830, also named "kaliapparat" (Figure 2), was beginning to revolutionize the science of chemistry with a wholly gravimetric procedure, especially for carbon and hydrogen analysis, that allowed getting at once fast, simple and precise results. ${ }^{15,16}$ The apparatus only showed deficiencies for the nitrogen analysis, which were later partially solved with improvements proposed by Dumas. ${ }^{17}$ The new equipment enabled users that even had not great skill on the subject not only to analyze with remarkable accuracy many more compounds that previous techniques, but also to do in a systematic way, on a large scale, substantial reductions in the time devoted to each analysis..$^{18,19}$

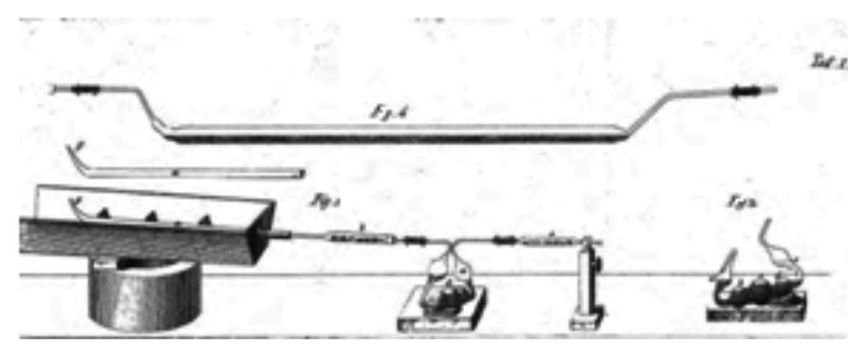

Figure 2. Model of Liebig's kaliapparat for hydrogen and carbon analysis used by Regnault ${ }^{15}$

The first Regnault's personal research in chemistry dealt with the oily liquid formed by the chlorination of ethylene (called then olefiant gas), namely ethylene dichloride, which became popularly known as Dutch liquor or liqueur des hollandais. This substance had been prepared by first time in 1794 by the Dutch chemists Johann Rudolph Deiman (1743-1808), Adrien Paets van Troostwijk (17521837), Nicolas Bondt (1765-1796) and Anthoni Lauwerenburgh 
(1758-1820), and the determination of its real composition became the subject of research of many chemists from the first quarter of the 19th century. ${ }^{20}$ The Dumas's results, which suggested the formula $\mathrm{C}_{4} \mathrm{H}_{8} \mathrm{Cl}_{4}\left(\mathrm{C}_{2} \mathrm{H}_{4} \mathrm{Cl}_{2}\right.$ in modern nomenclature), seemed to have received a general consensus from the chemical community, although the lack of an uniformly accepted table of atomic weights and the use of also different volume standards easily led to great confusion. ${ }^{21}$ A Liebig's criticism to the method followed for that determination allowed him to report a slightly different composition and to propose an also different formula for the compound $\left(\mathrm{C}_{8} \mathrm{H}_{15} \mathrm{Cl}_{8}\right)^{22}$.

Regnault understood that these seemingly little significant differences not only led to different formulas, but also would affect the study of its properties and decided to get involved in the subject to find the reasons for the discrepancies and the real formula for the compound. The research showed some of the qualities that would characterize the Regnault's style of work along his full career: meticulousness, high degree of accuracy, and scientific independence. ${ }^{23}$ By using the kaliapparat, Regnault was not only able to confirm the findings of Dumas, but also identified some technical limitations in the equipment and incomplete purification of the samples as the sources of error involved in the Liebig's research. Whilst conducting this research Regnault was also able to decompose Dutch oil by heating it with an alcoholic solution of potassium hydroxide, obtaining the monomer of vinyl chloride. Although he reported the formation of a white powder, which would be later identified as polyvinyl chloride (PVC) when the new compound was accidentally exposed to sunlight, the historical credit for the discovery of the polymer has been however given to the German chemist Eugen Baumann (1846-1896) in 1872 after noting some precipitated white flakes from vinyl chloride on a similar prolonged exposure in a sealed tube..$^{24}$

Before continuing the exposition of details, it is important to give a look to the scientific context in which the full research program was carried out in order to highlight its historical relevance. The electrochemical theory was being questioned and the chemical community was looking for a precise method to classify the each time greater number of new organic compounds appeared in the same way as the inorganic ones. A new mode of viewing chemical matters, by which radicals were considered as variable and chemical compounds recognized as possessed of a unitary character, seemed to make their way. The conception of equivalent was gradually taking shape to stand out from that of the atom, and unequivocally it had led to that of replacement in what Dumas would name later as the theory of substitution, or metalepsy. In the specific case treated here, Dumas, and few time later his compatriot Auguste Laurent (1807-1853), had showed about 1834 that the highly electro-negative chlorine could substitute equivalent per equivalent the electro-positive hydrogen in certain organic compounds, and play essentially the same role in the new formed compound. ${ }^{25}$ The radical was made up of an unchanged group of elements united among themselves more firmly than with other elements of the same compound, which remained intact in the different reactions where they were involved. The discovery of vinyl chloride would become, in concordance with these ideas, the first step of a whole research program that led Regnault not only to similarly obtain a numerous series of new compounds resulting from the progressive combination of chlorine with Dutch oil but also to, what it was most important, contribute to the definitive establishment of organic chemistry as an independent branch of the whole science. The corresponding chemical reaction successively produced a new chlorinated hydrocarbon and chlorhydric acid.

The second part of his research program allowed Regnault to identify the compound $\mathrm{C}_{4} \mathrm{H}_{6} \mathrm{Cl}_{2}$ as the chloride of the radical aldehydene $\left(\mathrm{C}_{4} \mathrm{H}_{6}\right)$, or, of the radical acetyl, as it was later called. He confirmed this hypothesis by preparing other chlorine, bromine and iodine compounds of this radical, which he also assumed to be present in aldehyde and acetic acid. ${ }^{26}$ The Table 1 shows (with the original notion) the formulas reported by Regnault for some of these compounds.

Table 1. Formulas of some organic compounds discovered by Regnault

\begin{tabular}{ll}
\hline Formula & Compound \\
\hline $\mathrm{C}_{4} \mathrm{H}_{6}$ & hypothetical radical aldehydene \\
$\mathrm{C}_{4} \mathrm{H}_{6}, \mathrm{Cl}_{2}$ & Chloraldehydene \\
$\mathrm{C}_{4} \mathrm{H}_{6}, \mathrm{Br}_{2}$ & Bromaldehydene \\
$\mathrm{C}_{4} \mathrm{H}_{6}, \mathrm{Cl}_{2}+\mathrm{H}_{2} \mathrm{Cl}_{2}$ & Chloride of hydrocarbon (ethylene chloride) \\
$\mathrm{C}_{4} \mathrm{H}_{6}, \mathrm{Br}_{2}+\mathrm{H}_{2} \mathrm{Br}_{2}$ & Bromide of hydrocarbon (ethylene bromide) \\
$\mathrm{C}_{4} \mathrm{H}_{6}, \mathrm{O}+\mathrm{H}_{2} \mathrm{O}$ & Aldehyde \\
$\mathrm{C}_{4} \mathrm{H}_{6} \mathrm{O}_{2}+\mathrm{H}_{2} \mathrm{O}$ & Aldehydic acid \\
$\mathrm{C}_{4} \mathrm{H}_{6}, \mathrm{O}_{3}+\mathrm{H}_{2} \mathrm{O}$ & Acetic acid \\
\hline
\end{tabular}

The investigation was surely prompted by Liebig, who, jointly with the also German Chemist Friedrich Wöhler (1800-1882), had carried out three years before a similar research on bitter almond oil and its derivatives. ${ }^{27}$ Before the year 1832 the only organic substance from which a number of simple derivatives had been obtained was alcohol, but the lack of a recognized and accepted method for ascertaining molecular weights led to a general speculation about the relationship among the original and the corresponding produced compounds. The situation was different when Regnault got involved in the subject and his performance did not go unnoticed for Liebig, who in a letter addressed to Berzelius on March 25, 1835 highlighted the importance of the new research and referred to him as "a talented young student" ${ }^{28}$ The research, one of the first few in the history of chemistry that allowed the obtaining of a series of numerous well defined compounds from one compound, joined to those carried out by the French chemists Faustino Malaguti $(\underline{1802}-1878)^{29}$ and Eugène-Melchior Péligot (1811-1890) ${ }^{30}$ in the confirmation the theory of substitutions, and contributed in some way to the later definitive formulation of the classification system of compounds according to chemical and mechanical types. ${ }^{31}$

The mentioned researches were shortly followed by the classical investigations on the action of chlorine on ethyl chloride, or monochloroethane, in which all the hydrogen atoms existing in the molecule were again successively replaced one by one by others of chlorine until the limit hexachloroethane was reached. ${ }^{32}$ The extremely careful experimental research that allowed the separate obtaining of each one of the different products was carried out in the schematic apparatus shown in Figure 3. The gas obtained by mixing equal volumes of alcohol and chlorine in the flask $A$ in one extreme was successively passed through the three bottles B, C and D, containing water, concentrated sulfuric acid, and again water, respectively. The chlorine generated in the opposite extreme of the apparatus from the manganese peroxide and hydrochloric acid introduced in flask I was also washed in the water in the bottle $\mathrm{H}$. The flask E exposed at least initially to the sunlight where both gases were conveyed was then arranged in such a way that the least volatile portion of the product was collected into the bottle $\mathrm{F}$ and the most volatile one in a well cooled bottle G. Very quickly Regnault identified isomerism between the series of products obtained in experimental substituting investigations from Dutch oil and from ethyl chloride, and proceeded to clearly characterize each one of them through the measurements of their very different physical and chemical properties.

Several decades after their discovery, the compounds discovered by Regnault found wide usefulness in the industry, mainly as noncom- 


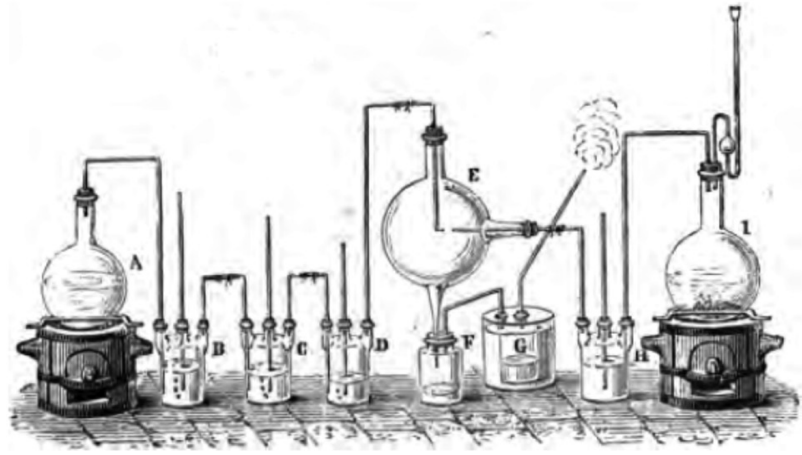

Figure 3. Apparatus used by Regnault in his researches on the action of chlorine on ethyl chloride ${ }^{33}$

bustible and nonflammable solvents for oils, fats and resins, replacing benzene and carbon sulfide. As additional results from these and other experimental researches in organic chemistry he carried out along five years, Regnault was also able to establish the change of ether into perchlorinated ether, to discover carbon tetrachloride by passing chlorine into boiling chloroform, ${ }^{34}$ to identify other organic and inorganic compounds such as sulfamide and chlorosulfuric acid and a new constitution for urea, ${ }^{35}$ sulfonaphthalic acid ${ }^{36}$ and to study the action of sulfuric acid on some organic compounds, ${ }^{37}$ among others.

\section{ALKAOLIDAL CHEMISTRY}

'Organic bases', later called alkaloids, was other subject in which Regnault showed interest in the first stage of his career. The subject was then a relatively new one. In 1803 the pharmacist Charles Louis Derosne (1780-1846) had isolated morphine from opium by first time ${ }^{38}$ and little time later his compatriot Friedrich Wilhelm Adam Sertürner (1783-1841) recognized its basic character and definitely characterized it as a vegetable alkali. ${ }^{39}$ By 1830 twenty-one alkaloids were known and the subject was the focus of the analytical attention of chemists, mainly because of their remarkable medicinal and physiological properties. ${ }^{40}$ The complicated structure of the first discovered alkaloids added one degree more of complexity to the already mentioned difficulty for classifying organic compounds whose composition, constitution and chemical behavior were very little understood in the same way as the newest inorganic substances got had their place within their far better ordered taxonomy. The presence of small quantities of nitrogen in the alkaloids made the methods more tedious because of the formation of more than one gaseous nitrogenous product as consequence of the corresponding analysis. This situation represented then a significant technical challenge for the contemporary chemists involved in the study of organic analysis in order to discover, at least, the elemental composition of the new substances.

Regnault's involvement in alkaloids was again influenced by Dumas and Liebig. Dumas began his research on this subject very early in his chemical career because of joint work with his fellow countryman and very experimented chemist Pierre Joseph Pelletier (1788-1842). Pelletier and Joseph-Bienaimé Caventau (1795-1877) had previously been able to extract, between 1817 and 1821, some alkaline nitrogenous substances ${ }^{41}$ such as strychnine in $1818,{ }^{42}$ brucine and veratrine in $1819,{ }^{43,44}$ and cinchonine and quinine in $1820,{ }^{45}$ and demonstrate that they contained oxygen, hydrogen, and carbon, but not, at least initially, nitrogen. It was in the later Pelletier's association with Dumas that both men, following a technique proposed by Gay-Lussac, not only proved conclusively the presence of nitrogen in alkaloids, but also reported with reasonable accuracy analysis of nine important alkaloids, though the large molecular weights resulted in some uncertainty in deducing formulas. ${ }^{46}$ Liebig's research program on organic chemistry, as it is suggested in the previous section, overlapped that of Dumas to a considerable extent. It had initially focused on the particular subject of alkaloids as a way to test his newly developed kaliapparat for the determination of the nitrogen content, in order to establish his analytical approach as a standard trustworthy technique of quantitative organic analysis. ${ }^{47}$ The subject was, nevertheless, not so simple, and the continuous criticisms of each other's practical techniques between Dumas and Liebig, in particular regarding the problematic determination of the nitrogen content, ${ }^{19}$ contributed to transform the scientific dispute in other one of personal character. According to this viewpoint, it seems that the underlying Liebig's purpose was the demonstration of superiority of his systematic alkaloid analysis over Dumas's one and uphold so his aspirations inside the European scientific upper class.

The low and slow level of acceptance of Liebig's proposed formulas for alkaloids inside the European chemical community and his interest for improve even more his experimental skill in the analytical techniques seem to have forced Regnault to enter in the subject, and incidentally in the personal dispute, in order to study some theories proposed about the general constitution of alkaloids. Although his initial specific interest was the verification of a generalization suggested by Liebig about the existence of a general and fixed number (two) of atoms of nitrogen in all these compounds, the full research led Regnault to correct some of the formulas determined by his master. By using the kaliapparat he determined the formulas of eleven known alkaloids (quinine, cinchonine, strychnine, brucine, morphine, codeine, narcotine, meconine, piperine, cantharidine and picrotoxine) and fourteen salts derived from them (sulfates of quinine, cinchonine, strychnine, brucine and morphine, nitrates of cinchonine, strychnine, brucine and urea, oxalate of quinine and urea, iodate of cinchonine, phosphate of strychnine, and acetate of quinine). ${ }^{48}$

Morphine was the key alkaloid at the moment to compare the different chemical formulas resulted from the studies of different scientists, very probably because of its great availability and widespread medicinal use. Dumas included it in his investigations with Pelletier, and for Liebig it was the first and most analyzed alkaloid along this stage of his career. Regnault's formula for this compound in 1838 curiously provoked an irate reaction from his German colleague, who rejected it because of was outside of the limit of accuracy the determination could provide; in his own words "whether [morphine] contains two atoms of hydrogen more or less, the analysis can give no information about this". ${ }^{49}$ Later essays and the course of time gave, however, the reason to Regnault.

The Table 2 includes the best molecular formulas deduced for several alkaloids by Dumas, Liebig and Regnault from their analytical results (jointly with the then widely adopted method vapor density measurements proposed by Dumas some years before), as well those actually accepted one for each compound. All the formulas have been adjusted according to the actual atomic weights lists in order to avoid the already mentioned confusion about the different tables used by these authors. Some of the formulas have also been reduced to unrounded atomic ratios for comparative purposes only. It is clear from the table that Regnault's formulas are closer to the actual one than those reported by his mentors for most of compounds included.

\section{CONCLUDING REMARKS}

Regnault did not follow a unified program of investigation in his chemical work. Although the collaborations discussed in this article have been considered the most valuable regarding chemistry in general, they were not the only he did in this field. The introduction he did of a new classification of the metals according to the facility 
Table 2. Comparative (reduced) formulas of different alkaloids

\begin{tabular}{lcccc}
\hline Alkaloid & Dumas & Liebig & Regnault & Actual \\
\hline Morphine & $\mathrm{C}_{15} \mathrm{H}_{20} \mathrm{NO}_{2.5}$ & $\mathrm{C}_{17} \mathrm{H}_{18} \mathrm{NO}_{3}$ & $\mathrm{C}_{17.5} \mathrm{H}_{20} \mathrm{NO}_{3}$ & $\mathrm{C}_{17} \mathrm{H}_{19} \mathrm{NO}_{3}$ \\
Strychnine & $\mathrm{C}_{30} \mathrm{H}_{30} \mathrm{~N}_{3} \mathrm{O}$ & $\mathrm{C}_{30} \mathrm{H}_{32} \mathrm{~N}_{2} \mathrm{O}_{3}$ & $\mathrm{C}_{21} \mathrm{H}_{22} \mathrm{~N}_{2} \mathrm{O}_{2}$ & $\mathrm{C}_{21} \mathrm{H}_{22} \mathrm{~N}_{2} \mathrm{O}_{2}$ \\
Cinchonine & $\mathrm{C}_{20} \mathrm{H}_{20} \mathrm{~N}_{2} \mathrm{O}_{1.5}$ & $\mathrm{C}_{20} \mathrm{H}_{22} \mathrm{~N}_{2} \mathrm{O}$ & $\mathrm{C}_{20} \mathrm{H}_{23} \mathrm{~N}_{2} \mathrm{O}$ & $\mathrm{C}_{19} \mathrm{H}_{22} \mathrm{~N}_{2} \mathrm{O}$ \\
Quinine & $\mathrm{C}_{20} \mathrm{H}_{20} \mathrm{~N}_{2} \mathrm{O}_{2}$ & $\mathrm{C}_{20} \mathrm{H}_{24} \mathrm{~N}_{2} \mathrm{O}_{2}$ & $\mathrm{C}_{20} \mathrm{H}_{24} \mathrm{~N}_{2} \mathrm{O}_{2}$ & $\underline{C}_{20} \underline{\mathrm{H}}_{24} \underline{N}_{2} \underline{\mathrm{O}}_{2}$ \\
Narcotine & $\mathrm{C}_{10} \mathrm{H}_{10} \mathrm{NO}_{2}$ & $\mathrm{C}_{20} \mathrm{H}_{20} \mathrm{NO}_{6}$ & $\mathrm{C}_{22} \mathrm{H}_{23} \mathrm{NO}_{6.5}$ & $\mathrm{C}_{22} \mathrm{H}_{23} \mathrm{NO}_{7}$ \\
Meconine & --- & --- & $\mathrm{C}_{10} \mathrm{H}_{10} \mathrm{O}_{4}$ & $\mathrm{C}_{10} \mathrm{H}_{10} \mathrm{O}_{4}$ \\
Piperine & --- & $\mathrm{C}_{20} \mathrm{H}_{20} \mathrm{NO}_{4}$ & $\mathrm{C}_{17} \mathrm{H}_{19} \mathrm{NO}_{3}$ & $\mathrm{C}_{17} \mathrm{H}_{19} \mathrm{NO}_{3}$ \\
\hline
\end{tabular}

with which they or their sulphides were oxidized by steam at high temperatures, the scientific review of the different known mineral combustibles according to their geologic ordering, composition and industrial application, and the comparative study of the chemical composition of atmospheric air from different parts of the world, are other of the researches he undertook along the short period of five years he strictly devoted to chemistry. The almost unanimous nomination, on July 6, 1840 to the chemical section of the Academie des Sciences to replace Pierre Jean Robiquet (1780-1840), as well the previously mentioned appointing as successor of Gay Lussac as professor of chemistry at the École Polytechnique, are facts that not only give clear evidence of the great reputation he had then gotten with an age of only thirty, but also shows that before physics, Regnault was a influential experimentalist in chemistry too. It were, nevertheless, his contributions to organic chemistry which incidentally placed him in the center of some of the several well-known disputes about the classification of organic compounds which characterized great part of that age, and, subsequently, in the 'hearth' of this new branch of science in the first half of the nineteenth century.

If it is true that the importance of this legacy is unquestionable, some of the features of his style of research and, in some way his scientific abilities, can to be a matter of discussion. Beginning with his researches in chemistry, and later with those in physics, Regnault created a whole new way of doing experiments in order to abolish as far as possible posterior corrections. In this way, he tried to control all disturbed parameters with an, until then unknown, extreme and persistent attention to detail and the search for the more appropriate experimental setup. The Dumas's words in referring to Regnault reveal the view which he and some of his contemporaneous colleagues had about his scientific style: "Defiant critic, no cause of error escapes him; ingenious spirit, he finds the art of avoiding all of them; completely exact scientist, instead of giving the average result of his experiments, he publishes all of the elements for discussion.... He introduces each characteristic method, he repeats and varies the experiments until the results identified are not in any doubt". ${ }^{50}$ This same strict and exclusive adherence to observable facts and the numerical results that emerged from the experimental inquiry that characterized his style opposed, however, viewpoints of others of his contemporaneous in chemistry, as, for example, Liebig. Whilst Regnault's style rejected whatever possibility for 'negotiate' with experimental results, Liebig believed that analysis alone was rarely sufficient to derive conclusions and give support for some constitutional theory. In opposite way to Regnault, Liebig was fond of teaching his students to incorporate a 'variety of factors', including the trust of the scientific community, in the process for choosing which results were worthy of publication and which not in order to gain acceptance for a particular conclusion. ${ }^{51}$

The strengths and weaknesses that identified the method followed by Regnault in his researches on chemistry were typical to his works in other branches of science, particularly in physics. ${ }^{3}$ His obsession for precision and the use of the most up-to-date techniques was ge- nerally accompanied by an inappropriate and unbalanced utilization of the conceptions of theory and experiment. It was reflected both in the planning of the experimental program and in the analysis of the corresponding results. The extreme cautiousness Regnault showed at carrying out his researches in chemistry had direct relation with his prejudice regarding the incorporation of some of the different existing theoretical assumptions mainly related with the chemical nature of the substances under analysis and the elements (and their number) existing in each compound. No one of those theories had yet shown to be true for the time Regnault was involved in these researches partially because of the lack of consensus on a uniform table of atomic weights, and it seems he was afraid they could be superseded by subsequent ones in the planning of experimental programs, thus affecting the reliability of his results. This situation forced him to use complicated mechanisms in complex apparatus for even the simplest phenomena in order to obtain reaction routes and formulas whose validity could not be scientifically questioned by the international chemical community. In the same way, the permanent fear of stating definite conclusions that could not be supported with certainty by his experimental data very probably prevent him of making theoretical contributions to science. This fact, which has been interpreted by historians as a partial lack of intellectual capacity, ${ }^{52}$ was also reflected in the textbooks he authored on chemistry. The publication, in four volumes, of his "Course elementaire de chimie" in 1847 (Figure 4), and that of "Premiers elements de chimie" two years later, became an editorial success in France (being translated into English, German, Dutch, Italian, and Spanish), but had a conflicting reception inside the scientific community. The more than 50,000 sold copies in France of the multi-volume very quickly became it, jointly with other by Pelouze ("Course de chimie générale"), in the most prominent French textbooks of the day. Its German edition was also one of the most popular organic chemical textbook in that country in the 1850 's. ${ }^{53}$ Written with a clearly pedagogic purpose, both Regnault's books were fiercely criticized because of the full absence there of an historical account of old theories and the corresponding credits for the responsible scientists, and, specially, for the lack of author's compromise in the discussion of opposite or exclusive scientific tendencies for specific subjects.

The direct influence Regnault received by different circumstances about scientific subjects from two of the most important figures of the then emerging organic analysis in France and Germany, Dumas and Liebig, ruled in some way his style of work. This fact did not affect, however, his scientific independence, at such point that great part of his reputation in this field is due to the demonstrations he did about the inaccuracy of their researches. It is difficult to speculate how the Regnault's career might to have been if he had continued to work on chemical matters instead of having devoted to the subjects related with physics for which is especially recognized. His appointment to a governmental commission charged with examining the safety and properties of steam engines was the opportunity he incidentally took advantage to demonstrate his attitude towards the experimental work 


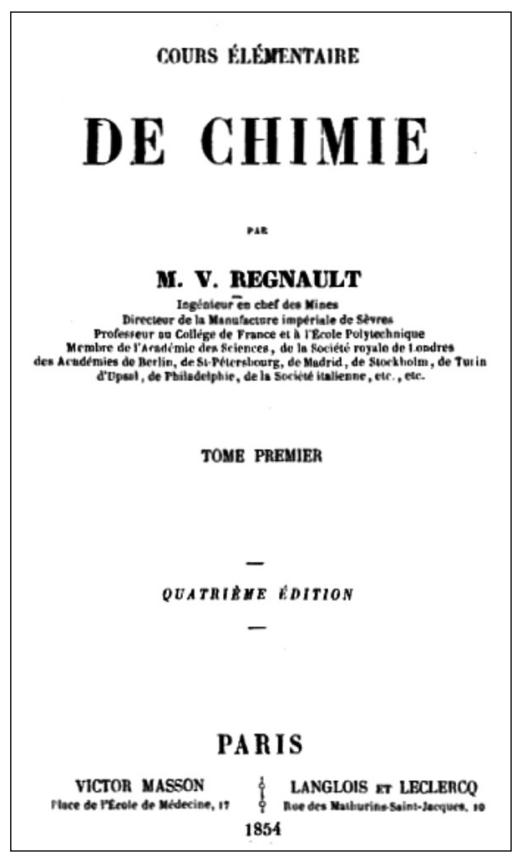

Figure 4. Cover page of the first volume of Regnault's Cours élémentaire de chimie, $4^{\text {th }}$ ed. $(1854)$

for to get definitively involved in the study of the properties of substances. The series of guided researches that led him to discover and study so numerous compounds, although almost completely ignored by modern historians, have also stood, however, the test of time, and become, from an experimental viewpoint, an example of meticulousness and a, probably some bit extreme, obsession for precision.

\section{REFERENCES}

1. Levere, T. H.; Transforming matter : a history of chemistry from alchemy to the buckyball, Johns Hopkins University Press: Baltimore, 2001; Ihde, A. J.; The development of modern chemistry, Dover: Mineola, 1984; Brock, W. H.; The Norton history of chemistry, W. W. Norton: New York, 1993; Knight, D.; Kragh, H., eds.; The making of the chemist : the social history of chemistry in Europe, 1789-1914, Cambridge University Press: Cambridge, 1998; Jaffe, B.; Crucibles; the story of the great chemists, The World Pub. Co.: Cleveland, 1942; Thorpe, E.; History of chemistry, Watts \& Co: London, 1909, vol. I.

2. Partington, J. R.; A short history of chemistry, $3^{\text {rd }}$ ed.; Dover: New York, 1989; Bensaude-Vincent, B.; Stengers, I.; A history of chemistry, Harvard University Press: Cambridge, 1996; von Meyer, E.; A history of chemistry from earliest times to the present day, MacMillan: London, 1906; Moore, F. J.; A history of chemistry, McGraw-Hill: New York, 1918.

3. Reif-Acherman, S.; Phys. Perspect. 2010, 12, 396.

4. Kreitmann, M. L.; Le centenaire de Victor Regnault, Barnéoud et Cie: Laval, 1911.

5. Daubrée, A.; C. R. Séances Acad. Sci. 1878, 86, 138.

6. Le Chatelier, H.; Centenaire de Victor Regnault: Discours pronouncé au College de France le 18 décembre 1910, Gauthier-Villars: Paris, 1910.

7. Daubrée, A.; Annales des Mines 1868, 14, 1; Kuslan, L. I. In Dictionary of Scientific Biography; Gilliespie, Ch. C., ed.; Scribner: New York, 1980, vol. 2 .

8. Crosland, M.; Gay-Lussac: Scientist and bourgeois, Cambridge University Press: Cambridge, 1978.

9. Anonymous; C. R. Séances Acad. Sci. 1840, 11, 900.

10. Fruton, J. S.; Proc. Amer. Phil. Soc. 1988, 132, 1.
11. Wankmüller, A.; Deuts. Apotheker-Zeit. 1967, 107, 463.

12. Holmes, F. L.; Osiris 1989, 5, 121.

13. Gay-Lussac, J. L.; Thenard, L. J.; Recherches physico-chimiques, Deterville: Paris, 1811; Gay-Lussac, J. L.; Ann. Chim. Phys. 1815, 95, 136; 1815, 96, 53; Berzelius, J. J.; Ann. Phil. 1814, 4, 323; 1814, 4, 401; $\mathbf{1 8 1 5}, 5,122$.

14. Liebig, J.; Gay-Lussac, J. L.; Ann. Chim. Phys. 1824, 25, 285.

15. Liebig, J.; Ann. Phys. 1831, 21, 1.

16. Liebig, J.; Ann. Chim. Phys. 1831, 47, 147.

17. Dumas, J.; Ann. Chim. Phys. 1833, 53, 164

18. Usselman, M. C.; Rocke, A. J.; Reinhart, C.; Foulser, K.; Ann. Sci. 2005, 62, 1; Morrell, J. B.; Ambix 1972, 19, 1; Brock, W.; Justus von Liebig: The chemical gatekeeper, Cambridge University Press: Cambridge, 1997.

19. Rocke, A. J. In Instruments and experimentation in the history of chemistry; Holmes, F. L; Levere, T. H., eds.; MIT Press: Cambridge, 2000.

20. Robiquet, P.-J.; Colin, J. J.; Ann. Chim. Phys. 1817, 1, 338; Morin, A.; Ann. Chim. Phys. 1830, 43, 225.

21. Dumas, J.; Ann. Chim. Phys. 1831, 48, 185.

22. Liebig, J.; Ann. Chim. Phys. 1832, 49, 146.

23. Regnault, H. V.; Ann. Chim. Phys. 1835, 58, 301.

24. Baumann, E.; Ann. Chem. Pharm. 1872, 163, 308.

25. Dumas, J.; Ann. Chim. Phys. 1834, 56, 113; Mem. Acad. Roy. Sci. Inst. France 1838, 15, 519; Laurent; Ann. Chim. Phys. 1835, 59, 376.

26. Regnault, H. V.; Ann. Chim. Phys. 1835, 59, 358.

27. Wöhler, F.; Liebig, J.; Ann. Chem. Pharm. 1832, 3, 249.

28. Carriere, J.; Berzelius und Liebig: Ihre briefe von 1831-1845, Lehmann: Munich, 1893.

29. Malaguti, F.; Ann. Chim. Phys. 1839, 70, 337.

30. Dumas, J.; Péligot, E.-M.; Ann. Chim. Phys. 1834, 57, 305.

31. Dumas, J.; C. R. Séances Acad. Sci. 1839, 8, 609; 1840, 10, 149; Phil. Mag 1840, 16, 322, 442, 501.

32. Regnault, H. V.; Ann. Chim. Phys. 1838, 69, 151; Robiquet, P. J.; Pelouze, T. J.; Dumas, J.; C. R. Séances Acad. Sci. 1839, 9, 789.

33. Regnault, H. V.; Course élémentaire de chimie, Mason: Paris, 1854, vol. 4.

34. Regnault, H. V.; Ann. Chim. Phys. 1839, 70, 104.

35. Regnault, H. V.; Ann. Chim. Phys. 1838, 69, 170.

36. Regnault, H. V.; Ann. Chim. Phys. 1837, 65, 87.

37. Regnault, H. V.; Ann. Chim. Phys. 1837, 65, 98.

38. Derosne, C. L.; Ann. Chim. Phys. 1802, 45, 257.

39. Sertürner, F. W. A.; J. Pharm. 1806, 14, 47; Schmitz, R.; Pharm. Hist. 1985, 27,61 .

40. Pictet, A.; The vegetable alkaloids, John Wiley: New York, 1913

41. Delepine, M.; J. Chem. Educ. 1951, 28, 454.

42. Pelletier, P. J.; Caventou, J.-B.; Ann. Chim. Phys. 1819, 10, 142.

43. Pelletier, P. J.; Caventou, J.-B.; Ann. Chim. Phys. 1819, 12, 113.

44. Pelletier, P. J.; Caventou, J.-B.; Ann. Chim. Phys. 1820, 14, 69.

45. Pelletier, P. J.; Caventou, J.-B.; Ann. Chim. Phys. 1820, 15, 289, 337; Analyse chimique des quinquina, Colas Fils: Paris, 1821.

46. Dumas, J.; Pelletier, P. J.; Ann. Chim. Phys. 1823, 24, 163.

47. Usselman, M. C.; Ambix 2003, 50, 71.

48. Regnault, H. V.; Ann. Chem. Pharm. 1838, 26, 10; Ann. Chim. Phys. 1838, 68,113 .

49. Wöhler, F.; Liebig, J.; Ann. Chem. Pharm. 1837, 22, 1.

50. Dumas, J.; Mém. Acad. Sci. Inst. France 1883, 42, xxxvii.

51. Liebig, J.; Ann. Chem. Pharm. 1834, 10, 203; Jackson, C. M.; Notes Rec. R. Soc. 2008, 62, 31 .

52. Fox, R. In Dictionary of Scientific Biography; Gilliespie, Ch. C., ed.; Scribner: New York, 1980, vol. 11.

53. Rocke, A. J.; Nationalizing science: Adolphe Wurtz and the battle for French chemistry, MIT Press: Cambridge, 2001. 